\title{
AKIBAT HUKUM TIDAK TERPENUHINYA SYARAT-SYARAT PEMBUATAN AKTA JUAL BELI OLEH NOTARIS
}

\author{
Ratri Puspita Suryandari, Lita Tyesta ALW., Adya Paramita Prabandari \\ Program StudiMagister Kenotariatan, \\ Fakultas Hukum, Universitas Diponegoro \\ E-mail : ratripuspita2nd@ gmail.com
}

\begin{abstract}
As an important proof of the ownership of a land, a notarial deed must fulfill the conditions that stipulated in the governed regulations. The unfulfilled conditions can lead to doubts about the authenticity of a deed, which can lead to a dispute. The purpose of this research is to find out the conditions that must be met in making a sale and purchase deed and also the legal consequences in terms of these conditions are not fulfilled. The research method used in this study is a normative juridical approach that is descriptive analytical. Based on the results of the study, it shows that 1.) Requirements that must be fulfilled in making a deed are the legal conditions of the agreement as well as the formal and material terms of the deed. 2.) Notary liability are based on the principle of "based on fault liability", in the form of civil, criminal and administrative liability.
\end{abstract}

\section{Keywords:Authentic Deed, Notary, Land, Dispute.}

\begin{abstract}
Abstrak
Sebagai suatu bukti penting untuk kepemilikan suatu hak atas tanah, akta Notaris harus memenuhi ketentuan atau syarat-syarat yang diatur dalam peraturan-peraturan yang mengaturnya. Tidak terpenuhinya syarat-syarat ini dapat menimbulkan keragu-raguan terhadap ke-autentikan dari suatu akta, sehingga dapat memicu adanya suatu sengketa.Tujuan diadakanya penelitian ini adalah untuk mengetahui syarat-syarat yang harus dipenuhi dalam pembuatan suatu akta jual beli dan juga akibat-akibat hukumnya dalam hal syarat-syarat tersebut tidak terpenuhi.Metode penelitian yang digunakan dalam penelitian ini adalah metode pendekatan yuridis normatif yang bersifat deskriptif analitis. Berdasarkan hasil penelitian, menunjukkan bahwa 1.) Syarat-syarat yang harus dipenuhi dalam pembuatan suatu akta jual beli adalah syarat sahnya perjanjian serta syarat formil dan syarat materiil akta. Tidak terpenuhinya syarat-syarat tersebut dapat menyebabkan degradasi kekuatan akta menjadi akta di bawah tangan, dapat dibatalkan, atau batal demi hukum 2.) Pertanggungjawaban Notaris didasarkan pada prinsip "based on fault liability", dengan bentuk pertanggungjawaban secara perdata, pidana, dan administrasi.
\end{abstract}

Kata kunci : Akta Autentik; Notaris; Tanah; Sengketa.

\section{A. Pendahuluan}

Tanah merupakan suatu kepentingan primer yang dibutuhkan oleh setiap orang. Tanah tersebut berguna untuk menunjang kehidupan, baik sebagai alas mendirikan tempat tinggal, aset kepemilikan, maupun sebagai modal mendirikan suatu usaha. Undang-Undang Nomor 5 Tahun 1960 tentang Peraturan Dasar Pokok-Pokok Agraria (UUPA) merupakan Undang- 
Undang yang mengatur mengenai tanah beserta dasar hukum kepemilikan tanah di Indonesia. Tujuan diundangkannya UUPA ini ada didalam Penjelasan Umum UUPA, yaitu:

a. Meletakkan dasar-dasar bagi penyusunan Hukum Agraria Nasional yang akan merupakan alat untuk membawakan kemakmuran, kebahagiaan, dan keadilan bagi negara dan rakyat terutama rakyat tani dalam rangka masyarakat yang adil dan makmur;

b. Meletakkan dasar-dasar untuk mengadakan kesatuan dan kesederhanaan dalam Hukum Pertanahan;

c. Meletakkan dasar-dasar untuk memberikan kepastian hukum mengenai hak-hak atas tanah bagi rakyat seluruhnya.

Berdasarkan tujuan pada poin ketiga tersebut, dapat dilihat bahwa salah satu tujuan dari UUPA adalah memberikan kepastian hukum mengenai hak-hak penguasaan atas tanah yang ada.

Pasal 4 ayat (1) UUPA menyebutkan: "atas dasar hak menguasai negara atas tanah sebagai yang dimaksud dalam Pasal 2 ditentukan adanya macam-macam hak atas permukaan bumi, yang disebut tanah, yang dapat diberikan kepada dan dipunyai oleh orangorang baik sendiri maupun bersama-sama dengan orang lain serta badan-badan hukum". Boedi Harsono menyatakan bahwa yang dimaksud hak penguasaan atas tanah adalah serangkaian wewenang, kewajiban, dan/atau larangan bagi pemegang haknya untuk berbuat sesuatu mengenai tanah yang dihakinya.(Santoso, 2017a)

Terdapat berbagai jenis hak atas tanah, yang kemudian dibedakan menjadi dua macam kelompok, yaitu:

a. Primer

Hak atas tanah yang berasal dari tanah negara, seperti Hak Milik, Hak Guna Usaha, (HGU), Hak Guna Bangunan (HGB) dan Hak Pakai.

b. Sekunder

Hak atas tanah yang berasal dari tanah pihak lain, seperti Hak Sewa, Hak Pakai atas tanah Hak Pengelolaan dan HGB atas tanah Hak Milik.

Perolehan hak atas tanah diatas dapat terjadi melalui 2 (dua) cara, yaitu:(Santoso, 2017b)

a. Originair

Perolehan hak atas tanah yang terjadi untuk pertama kali melalui penetapan Pemerintah, atau karena ketentuan undang-undang (penegasan konversi).

Bentuknya berupa hak atas tanah yang lahir atas tanah yang berasal dari tanah negara melalui permohonan pemberian hak atasnegara, perolehan Hak Guna Bangunan atau Hak Pakai yang berasal dari tanah Hak Pengelolaan, Hak Guna Bangunan lahir dari 
penurunan Hak Milik, Hak Milik lahir dari peningkatan Hak Guna Bangunan, dan Hak Milik dari penegasan konversi bekas tanah milik adat.

b. Derivatif

Perolehan hak atas tanah yang terjadidari tanah yang dimiliki atau dikuasai oleh pihak lain melalui peralihan hak atas tanah.

Perolehan ini dapat terjadi melalui pemindahan hak dalam bentuk jual beli, tukar menukar, hibah, pemasukan dalam modal perusahaan (inbreng), atau lelang, dapat juga melalui pewarisan.

Jual beli merupakan salah satu cara untuk mengalihkan hak atas tanah yang telah ada sejak jaman dahulu dan telah diatur oleh hukum adat dengan menggunakan prinsip "Terang dan Tunai”. Dewasa ini, yang diberi wewenang untuk melaksanakan jual beli adalah Pejabat Pembuat Akta Tanah (PPAT), yang terdiri dari:(Purnamasari, 2010a)

a. PPAT yang merupakan pejabat umum dan biasanya juga berprofesi sebagai notaris,atau yang telah lulus dari pendidikan spesialisasi Kenotariatan dan Pertanahan (sekarang Magister Kenotariatan) dan telah lulus ujian PPAT serta diangkat berdasarkan Surat Keputusan dari Menteri Negara Agraria/Kepala Badan Pertanahan Nasional untuk wilayah kerja tertentu;

b. PPAT sementara, yaitu pejabat pemerintah yang ditunjuk karena jabatannya untuk melaksanakan tugas PPAT dengan membuat akta PPAT di daerah yang belum cukup terdapat PPAT;

c. PPAT khusus adalah pejabat BPN yang ditunjuk karena jabatannya untuk melaksanakan tugas PPAT dengan membuat akta PPAT tertentu, khusus dalam rangka pelaksanaan program atau tugas pemerintah tertentu.

Dalam jual beli atau peralihan hak atas tanah, seorang Notaris dalam pembuatan akta autentik harus memperhatikan ketentuan-ketentuan yang mengatur mengenai perbuatan hukum maupun syarat-syarat pembuatan suatu akta tersebut.Ketentuan dan syarat ini mengatur baik format dari akta maupun kewajiban-kewajiban yang harus dipenuhinya sebagai pejabat umum dalam pembuatan akta tersebut.Undang-Undang Nomor 2 Tahun 2014 tentang Perubahan Atas Undang-Undang Nomor 30 Tahun 2004 tentang Jabatan Notaris dan Kode Etik Notaris merupakan aturan pokok yang harus ditaati oleh seorang Notaris dalam menjalankan jabatannya, dalam hal ini adalah membuat akta autentik dengan memperhatikan aturan-aturan lainnya yang juga mengatur mengenai perbuatan hukum yang hendak dilakukan. 
Ketentuan yang mengatur mengenai format dan kewajiban-kewajiban Notaris dalam pembuatan akta ini menjadi suatu tolak ukur sah atau tidaknya suatu akta yang telah dibuat oleh Notaris. Dalam hal ketentuan-ketentuan tersebut tidak diindahkan atau dipenuhi oleh Notaris, dapat berpengaruh pada keautentikan suatu akta.Dalam proses peralihan hak atas tanah melalui jual beli, kekuatan suatu akta yang dibuat oleh seorang notaris sangat berpengaruh terhadap peralihan hak yang terjadi. Apabila akta yang dibuat oleh seorang notaris tersebut diduga mengandung suatu cacat hukum, hal ini dapat menimbulkan suatu perselisihan atau sengketa terhadap kepemilikan obyek hukum yang tercantum didalam akta tersebut.

Eratnya keterkaitan antara tugas, fungsi, kewajiban dan tanggungjawab notaris dalam menjalankan jabatannya untuk membuat akta autentik terhadap sah atau tidaknyaperalihan hak atas tanah dalam proses jual beli ini, menarik perhatian penulis untuk menelitinya dalam sebuah karya tulis dengan judul "Akibat Hukum Tidak Terpenuhinya Syarat-syarat Pembuatan Akta Jual Beli Oleh Notaris".

- Kerangka Teori

Peralihan hak atas tanah melalui jual beli merupakan suatu proses berpindahnya hak atas tanah dari satu pihak kepada pihak lainnya melalui suatuperbuatan hukumyang tertuang di dalam akta sebagai bukti tertulis yang dibuat oleh pejabat umum yaitu Notaris sekaligus PPAT. Peran serta notaris dalam menjalankan jabatannya dengan memenuhi segala ketentuan yang mengaturnya dalam pembuatan suatu akta sangat menentukan sah atau tidaknya perpindahan hak yang terjadi. Akta jual beli yang dibuat oleh seorang Notaris merupakan akta autentik yang harus memenuhi syarat-syarat yang telah diatur didalam peraturan perundang-undangan. Tidak terpenuhinya syarat-syarat tersebut dapat menimbulkan akibat hukum baik terhadap kekuatan akta maupun perbuatan hukum yang tertuang didalamnya.

- Permasalahan

Berdasarkan latar belakang permasalahan yang telah diuraikan sebelumnya, penulis merasa perlu adanya suatu penelitian guna mengetahui beberapa hal. Pertama, syarat dan ketentuan apa saja yang harus dipenuhi oleh seorang notaris dalam membuat suatu akta, serta apa akibat hukumnya dalam hal persyaratan tersebut tidak terpenuhi. Kedua,bagaimana pertanggung jawaban notaris terhadap akta yang dibuatnya.

Tujuan dilakukannya penelitian ini adalah untuk mengetahui syarat-syarat dari suatu akta, akibat hukumnya dalam hal persyaratan tersebut tidak terpenuhi, serta sejauh mana 
pertanggungjawaban notaris terhadap aktanya dalam hal adanya suatu pelanggaran yang dilakukan oleh notaris tersebut.

- Kebaruan/Orisinalitas Hasil Penelitian

Berdasarkan penelusuran kepustakaan yang telah dilakukan oleh penulis ke berbagai sumber di perpustakaan, media cetak, maupun media internet, terdapat beberapa penelitian yang berkaitan dengan akta jual beli, akan tetapi terdapat perbedaan fokus penelitian. Penelitian tersebut diantaranya penelitian yang dilakukan oleh:

a. Ardiansyah Zulhadji(Zulhadji, 2016a)yang berjudul Peralihan Hak Atas Tanah Melalui Jual Beli Tanah Menurut Undang Undang Nomor 5 Tahun 1960, dengan rumusan masalah:

1) Bagaimanakah pelaksanaan peralihan hak atas tanah melalui jual beli tanah menurut UUPA?

2) Kendala apakah yang dihadapi dalam pelaksanaan peralihan hak atas tanah melalui jual beli tanah menurut UUPA?

Secara garis besar kesimpulan dari penelitian Ardiansyah Zulhadji ini adalah jual beli merupakan salah satu cara pelaksanaan peralihan hak atas tanah yang dalam UUPA disebut dengan menggunakan istilah "dialihkan" dimana jual beli adalah suatu persetujuan dengan mana pihak yang satu mengikatkan dirinya untuk menyerahkan suatu kebendaan, dan pihak yang lain untuk membayar harga yang telah diperjanjikan yang memiliki kendala bilamana dalam proses jual beli tersebut penjual atau pemilik tanah kehilangan sama sekali hak yang dimilikinya.

b. Kunni Afifah(Afifah, 2017a) yang berjudul Tanggung Jawab dan Perlindungan Hukum bagi Notaris secara Perdata Terhadap Akta yang Dibuatnya, dengan rumusan masalah:

1) Bagaimanakah pertanggungjawaban Notaris secara perdata terhadap akta-akta yang dibuatnya?

2) Bagaimanakah perlindungan hukum bagi Notaris terhadap akta-akta yang dibuatnya terkait pertanggungjawaban Notaris secara perdata?

Secara garis besar kesimpulan dari penelitian Kunni Afifah ini adalah selain adanya suatu bentuk pertanggungjawaban seorang Notaris terhadap aktanya yaitu dengan penjatuhan sanksi perdata berupa penggantian biaya atau ganti rugi kepada pihak yang terbukti dirugikan atas perbuatan melawan hukum yang dilakukan oleh Notaris, seorang Notaris juga mendapatkan suatu bentuk perlindungan hukum yang diperolehnya dengan adanya Majelis Kehormatan Notaris yang bersifat independen. 
c. Giovanni Rondonuwu(Rondonuwu, 2017a) yang berjudul Kepastian Hukum Peralihan Hak Atas Tanah Melalui Jual Beli Berdasarkan PP Nomor 24 Tahun 1997 Tentang Pendaftaran Tanah, dengan rumusan masalah:

1) Bagaimana prosedur peralihan hak atas tanah melalui jual beli menurut PP No. 24 Tahun 1997 tentang Pendaftaran Tanah?

2) Bagaimana kepastian hukum peralihan hak atas tanah melalui jual beli menurut PP Nomor 24 Tahun 1997 tentang Pendaftaran Tanah?

Secara garis besar kesimpulan dari penelitian Giovanni Rondonuwu ini adalah peralihan hak atas tanah melalui jual beli berdasarkan PP No 24 Tahun 1997 harus memenuhi syarat materiil dan syarat formil, mencakup bukti kepemilikan yang sah dari penjual guna menjamin kepastian hukum peralihan hak atas tanah yang terjadi.

\section{B. Metode Penelitian}

Penelitian ini menggunakan metode penelitian yuridis normatif, dimana peneliti mempelajari norma-norma yang terdapat didalam peraturan-peraturan perundang-undangan yang berlaku sebagai suatu koridor hukum dalam pembuatan suatu akta jual beli, guna mengetahui ketentuan-ketentuan yang harus dipenuhi beserta akibat hukum yang ditimbulkannya.

\section{Hasil Dan Pembahasan}

\section{Syarat dan Ketentuan yang Harus Dipenuhi Oleh Notaris dalam Membuat Akta} Jual Beli

a. Pengertian Jual Beli

Jual beli adalah menukar barang dengan barang atau menukar barag dengan uang, dengan melepaskan hak kepemilikan dari yang satu kepada yang lain atas dasar saling merelakan (Sarwat, 2018).Jual beli ini merupakan salah satu cara perolehan hak atas tanah yang dilakukan secara derivatif. Maksud dari derivatif yaitu adalah perolehan hak atas tanah yang terjadi dari tanah yang dimiliki atau dikuasai oleh pihak lain melalui peralihan hak atas tanah. Perolehan ini dapat terjadi melalui pemindahan hak dalam bentuk jual beli, tukar menukar, hibah, pemasukan dalam modal perusahaan (inbreng), atau lelang, dapat juga melalui pewarisan (Santoso, 2017b).

Didalam UUPA, penyebutan mengenai jual beli ini ini hanya terdapat dalam Pasal 26 yaitu“jual beli, penukaran, penghibahan, pemberian dengan wasiat, 
pemberian menurut adat dan pemberian-pemberian lain yang dimaksudkan untuk memindahkan hak milik serta pengawasannya diatur dengan Peraturan Pemerintah”.(Undang-Undang Republik Indonesia Nomor 5 Tahun 1960 Tentang Peraturan Dasar Pokok-Pokok Agraria, 1960).Berdasarkan pasal tersebut, jual beli merupakan salah satu cara untuk mengalihkan hak atas tanah. Penjelasan mengenaijual beli itu sendiri oleh UUPA tidak diterangkan secara jelas, akan tetapi mengingat Pasal 5 UUPA disebutkan bahwa Hukum Tanah Nasional kita adalah Hukum Adat, berarti menggunakan konsepsi, asas-asas, lembaga hukum, dan sistem Hukum Adat (Zulhadji, 2016b). Hukum-hukum Adat yang dimaksud disini merupakan Hukum Adat yang telah di-saneer atau dibersihkan dari unsur-unsur yang bertentangan dengan jiwa Pancasila.Oleh hukum adat,prinsip "Terang dan Tunai" digunakan dalam pengaturan jual beli. "Terang" yang berarti dilakukan secara terbuka, jelas baik objek, subjek, maupun surat-surat bukti kepemilikannya, sedangkan "tunai" yang berarti dibayar seketika dan sekaligus.

Berdasarkan PP Nomor 24 Tahun 1997 tentang Pendaftaran Tanah, peralihan tanah dan benda-benda diatasnya dilakukan dengan akta PPAT. PPAT yang dimaksud disini terdiri dari:(Purnamasari, 2010a)

1) PPAT yang merupakan pejabat umum dan biasanya juga berprofesi sebagai notaris,atau yang telah lulus dari pendidikan spesialisasi Kenotariatan dan Pertanahan (sekarang Magister Kenotariatan) dan telah lulus ujian PPAT serta diangkat berdasarkan Surat Keputusan dari Menteri Negara Agraria/Kepala Badan Pertanahan Nasional untuk wilayah kerja tertentu;

2) PPAT sementara, yaitu pejabat pemerintah yang ditunjuk karena jabatannya untuk melaksanakan tugas PPAT dengan membuat akta PPAT di daerah yang belum cukup terdapat PPAT;

3) PPAT khusus adalah pejabat BPN yang ditunjuk karena jabatannya untuk melaksanakan tugas PPAT dengan membuat akta PPAT tertentu, khusus dalam rangka pelaksanaan program atau tugas pemerintah tertentu.

Notaris yang sekaligus merangkap jabatan sebagai PPAT, untuk menjalankan jabatannya dalam suatu jual beli, harus memastikan bahwa syarat-syarat jual beli terpenuhi. Mengingat jual beli ini merupakan cara peralihan hak atas tanah yang sudah ada sejak jaman dahulu, maka pengaturannya pun tidak hanya ada di peraturan perundang-undangan, melainkan juga di dalam hukum adat yang ada di Indonesia. Syarat-syarat jual beli ada dalam hukum adat dan pada perundang-undangan yang 
diatur dalam Pasal 37 ayat (1) PP Nomor 24 Tahun 1997 tantang Pendaftaran Tanahyang masing-masing dibagi menjadi 2 (dua) macam yaitu materiil dan formil, antara lain:

1) Hukum Adat

a) Materiil

Penjual dan pembeli harus sebagai subyek yang sah menurut hukum dari tanah yang diperjual-belikan.

b) Formil

Jual beli tersebut dilakukan dihadapan kepala desa (kepala adat) di mana tanah yang diperjual-belikan tersebut terletak.

2) Pasal 37 ayat (1) PP No. 24 Tahun 1997 tentang Pendaftaran Tanah(Rondonuwu, 2017b)

a) Materiil

(1) Penjual adalah orang yang berhak atas tanah yang akan dijualnya;

(2) Pembeli adalah orang yang berhak untuk mempunyai hak atas tanah yang dibelinya;

(3) Tanah yang bersangkutan boleh diperjual-belikan atau tidak dalam sengketa.

b) Formal

Syarat formal dari jual belihak atas tanah merupakan formalitas transaksi jual beli tersebut. Formalitas tersebut meliputi akta yang menjadi bukti perjanjian jual beli serta pejabat yang berwenang membuat akta tersebut. Dalam rangka pendaftaran pemindahan hak, maka syarat formil jual beli hak atas tanah harus dibuktikan dengan akta yang dibuat oleh dan dihadapan pejabat pembuat akta tanah (PPAT).

b. Pengertian Akta dan Notaris

Akta adalah surat yang dijadikan sebagai alat bukti yang diberi tanda tangan yang memuat peristiwa yang menjadi dasar suatu hak atau perikatan, yang dibuat sejak semula dengan sengaja untuk pembuktian.(Mertokusumo, 1981)Istilah akta berasal dari bahasa Belanda yaitu Akte yang kemudian diartikan dalam dua pendapat, yang pertama yaitu diartikan sebagai surat dan yang kedua diartikan sebagai perbuatan hukum.(Samudera, 2004) Secara umum, akta ini dapat diartikan sebagai suatu surat yang ditandatangani dan dibuat sebagai bukti suatu perbuatan hukum. 
Akta dibagi menjadi 2 jenis, yaitu akta autentikdan akta dibawah tangan. Pengertian dari akta autentik dijabarkan dalam Pasal 1868 Kitab Undang-Undang Hukum Perdata (KUH Perdata), yaitu suatu akta yang didalam bentuk yang ditentukan oleh undang-undang, dibuat oleh atau dihadapan pegawai-pegawai umum yang berkuasa untuk itu di tempat dimana akta dibuatnya. Sedangkan pengertian dari akta di bawah tangan dapat kita lihat pada rumusan Pasal 1874 KUH Perdata, yaitu sebagai tulisan-tulisan dibawah tangan dianggap akta-akta yang ditandatangani di bawah tangan, surat-surat, register-register, surat-surat urusan rumah tangga dan lainlain tulisan yang dibuat tanpa perantaraan seorang pegawai umum. Menurut Laurensius, perbedaan dari kedua akta ini yaituakta autentik dibuat dalam bentuk yang ditentukan oleh Undang-Undang oleh atau dihadapan pejabat umum yang berwenang untuk itu, sedangkan akta di bawah tangan tidak dilakukan oleh dan atau dihadapan pejabat pegawai umum namun cukup oleh pihak yang berkepentingan saja.(Simbolon, 2015).

Berdasarkan rumusan Pasal 1868 KUH Perdata, Supancana mengemukakan syarat dari suatu akta autentik, antara lain:(Supancana, 2019)

1) Dibuat oleh atau dihadapan pejabat umum (openbaar ambtenaar) yang berwenang dan cakap;

2) Menggunakan format tertentu yang ditetapkan oleh undang-undang;

3) Dihadiri saksi-saksi;

4) Disertai pembacaan oleh notaris;

5) Sesudahnya langsung ditandatangani.

Melihat dari syarat-syarat akta autentik tersebut diatas, dapat kita lihat bahwa diperlukan adanya keterlibatan pejabat umum untuk dapat membuat suatu akta autentik. Sehingga tanpa adanya pejabat umum tersebut, maka surat atau akta yang dihasilkan atau dibuat tidak dapat disebut sebagai akta autentik. Berdasarkan Pasal 1874 KUH Perdata, segala surat yang dibuat tanpa perantara pejabat umum tersebut, disebut dengan akta di bawah tangan.

Sebagai kepanjangan tangan pemerintahdalam melaksanakan pelayanan publik, Notaris diposisikan sebagai pejabat umum yang mengemban tugas dan satu-satunya pejabat umum yang berhak membuat akta autentik sebagai alat pembuktian yang paling sempurna.(Pengurus Pusat Ikatan Notaris Indonesia, 2008). Fungsi dari Notaris ini sejalan dengan pengertian yang disebutkan dalam Pasal 1 angka 1 UUJN, yaitu "Notaris adalah pejabat umum yang berwenang untuk membuat akta autentik 
dan kewenangan lainnya sebagaimana dimaksud dalam undang-undang ini atau berdasarkan undang-undang lainnya".(Undang-Undang Republik Indonesia Nomor 2 Tahun 2014 Tentang Perubahan Atas Undang-Undang Nomor 30 Tahun 2004 Tentang Jabatan Notaris, 2004)

Kewenangan dari seorang Notaris dijabarkan lebih lanjut dalam Pasal 15 ayat (1) UUJN, yaitu:

"Notaris berwenang membuat akta autentik mengenai semua perbuatan, perjanjian dan ketetapan yang diharuskan oleh peraturan perundang-undangan dan/atau yang dikehendaki oleh yang berkepentingan untuk dinyatakan dalam akta autentik, menjamin kepastian tanggal pembuatan akta, menyimpan akta, memberikan grosse, salinan dan kutipanakta, semuanya itu sepanjang pembuatan akta-akta itu tidak juga ditugaskan atau dikecualikan kepada pejabat lain atau orang lain yang ditetapkan oleh undang-undang."(UndangUndang Republik Indonesia Nomor 2 Tahun 2014 Tentang Perubahan Atas Undang-Undang Nomor 30 Tahun 2004 Tentang Jabatan Notaris, 2004)

Fungsi notaris di bidang pekerjaannya yaitu berkewajiban dan bertanggungjawab terutama atas pembuatan akta autentik yang telah dipercayakan kepadanya, khususnya di bidang hukum perdata.(Moechthar, 2019)Ketentuan pembuatan akta autentik bagi Notaris diatur didalam Pasal 38, Pasal 39, dan Pasal 40 UUJN, yang mencakup bentuk fisik dari akta maupun pihak-pihak yang terlibat dalam proses pembuatan dari akta itu sendiri.Pasal 38 menjelaskan bahwa:

1) Setiap akta Notaris terdiri atas:

a) Awal akta atau kepala akta;

b) Badan akta;

c) Akhir atau penutup akta.

2) Awal akta atau kepala akta memuat:

a) Judul akta;

b) Nomor;

c) Jam, hari, tanggal, bulan, dan tahun;

d) Nama lengkap dan tempat kedudukan Notaris.

3) Badan akta memuat:

a) Nama lengkap, tempat dan tanggal lahir, kewarganegaraan, pekerjaan, jabatan, kedudukan, tempat tinggal para penghadap dan/atau orang yang mereka wakili;

b) Keterangan mengenai kedudukan bertindak para penghadap; 
c) Isi akta yang merupakan kehendak dan keinginan dari pihak yang berkepentingan;Nama lengkap, tempat dan tanggal lahir, serta pekerjaan, jabatan, kedudukan, dan tempat tinggal dari tiap-tiap saksi pengenal.

4) Akhir atau penutup akta memuat:

a) Uraian tentang pembacaan akta sebagaimana dimaksud dalam Pasal 16 ayat (1) huruf m atau Pasal 16 ayat (7);

b) Uraian tentang penandatanganan dan tempat penandatanganan atau penerjemah akta apabila ada;

c) Nama lengkap, tempat dan tanggal lahir, pekerjaan, jabatan, kedudukan, dan tempat tinggal dari tiap-tiap saksi akta;

d) Uraian tentang tidak adanya perubahan yang terjadi dalam pembuatan akta atau uraian tentang adanya perubahan yang dapat berupa penambahan, pencoretan, atau penggantian.

5) Akta Notaris Pengganti, Notaris Pengganti Khusus, dan Pejabat Sementara Notaris, selain memuat ketentuan sebagaimana dimaksud pada ayat (2), ayat (3), dan ayat (4), juga memuat nomor dan tanggal penetapan pengangkatan, serta pejabat yang mengangkatnya.

Sedangkan Pasal 39 menjelaskan:

1) Penghadap harus memenuhi syarat sebagai berikut:

a) Paling rendah berumur 18 (delapan belas) tahun atau telah menikah; dan

b) Cakap melakukan perbuatan hukum.

c) Penghadap harus dikenal oleh Notaris atau diperkenalkan kepadanya oleh 2 (dua) orang saksi pengenal yang berumur paling rendah 18 (delapan belas) tahun atau telah menikah dan cakap melakukan perbuatan hukum atau diperkenalkan oleh 2 (dua) penghadap lainnya;

d) Pengenalan sebagaimana dimaksud pada ayat (2) dinyatakan secara tegas dalam Akta.

Adapun Pasal 40 menjelaskan:

1) Setiap Akta yang dibacakan oleh Notaris dihadiri paling sedikit 2 (dua) orang saksi, kecuali peraturan perundang-undangan menentukan lain;

2) Saksi sebagaimana dimaksud pada ayat (1) harus memenuhi syarat sebagai berikut:

a) Paling rendah berumur 18 (delapan belas) tahun atau sebelumnya telah menikah; 
b) Cakap melakukan perbuatan hukum;

c) Mengerti bahasa yang digunakan dalam akta;

d) Tidak mempunyai hubungan perkawinan atau hubungan darah dalam garis lurus ke atas atau ke bawah tanpa pembatasan derajat dan garis ke samping sampai dengan derajat ketiga dengan Notaris atau para pihak.

e) Saksi sebagaimana dimaksud pada ayat (1) harus diperkenalkan kepada Notaris atau diterangan tentang identitas dan kewenangannya kepada Notaris oleh penghadap;

f) Pengenalan atau pernyataan tentang identitas dan kewenangan saksi dinyatakan secara tegas dalam Akta.

Ketentuan yang diatur didalam Pasal 41, menjelaskan bahwa pelanggaran terhadap ketentuan sebagaimana dimaksud dalam Pasal 38, Pasal 39, dan Pasal 40 mengakibatkan akta hanya mempunyai kekuatan pembuktian sebagai akta di bawah tangan. Selaras dengan Pasal 41 ini, Moechthar mengatakan apabila ketentuan ini dilanggar, mengakibatkan suatu akta hanya mempunyai kekuatan pembuktian sebagai akta di bawah tangan atau suatu akta menjadi batal demi hukum.(Moechthar, 2017)

\section{c. Proses Jual Beli}

Dalam suatu transaksi jual beli properti ada 2 (dua) perbuatan hukum yang dilakukan, yakni perbuatan hukum yang menyangkut jual beli itu sendiri dan perbuatan hukum pengalihan hak kepemilikan barang yang menjadi objek jual beli.(Kuncoro, 2015) Notaris sebagai pejabat yang berwenang dalam pembuatan akta autentik dan membantu dalam proses jual beli tersebut, akan meminta data standart, meliputi: (Purnamasari, 2010b)

1) Data tanah

a) PBB asli lima tahun terakhir berikut surat tanda terima setoran (bukti bayarnya);

b) Sertipikat asli tanah;

c) Asli Izin Mendirikan Bangunan (IMB);

d) Bukti pembayaran rekening listrik, telepon, air (bila ada);

e) Jika masih dibebani Hak Tanggungan, harus dilampirkan pula sertipikat hak tanggungan asli atas tanah dan bangunan dimaksud, yang dilengkapi dengan surat lunas dan asli surat roya dari bank yang bersangkutan.

2) Data Penjual dan Pembeli 
a) Fotokopi Kartu Tanda Penduduk suami/isteri Penjual dan Pembeli;

b) Fotokopi Kartu Keluarga dan Akta Nikah;

c) Fotokopi NPWP Penjual dan Pembeli.

Persyaratan diatas wajib dibawa aslinyadan diperlihatkan kepada Notaris.

Setelah semua data-data yang dibutuhkan lengkap, maka notaris dapat melanjutkannya dengan pembuatan akta jual beli, yaitu suatu akta autentik yang berisi perjanjian pengikatan satu pihak pada pihak lainnya untuk menyerahkan dan mengalihkan hak kepemilikan suatu benda yang dalam hal ini adalah hak atas tanah.

Pengalihan kepemilikan hak atas tanah yang hanya dilakukan dengan akta jual beli oleh notaris ini belumlah sempurna. Pasal 23 ayat (2) UUPA menyebutkan"Pendaftaran termasuk dalam ayat (1) merupakan alat pembuktian yang kuat mengenai hapusnya hak milik serta sahnya peralihan dan pembebanan hak tersebut.”(Undang-Undang Republik Indonesia Nomor 5 Tahun 1960 Tentang Peraturan Dasar Pokok-Pokok Agraria, 1960) Proses pendaftaran ini diatur di dalam Pasal 22 PP Nomor 10 Tahun 1961 Tentang Pendaftaran Tanah, yang menyebutkan:

"Akta termaksud dalam ayat (1) pasal ini beserta sertifikat dan warkah lain yang diperlukan untuk membuat akta itu oleh Pejabat segera disampaikan kepada Kantor Pendaftaran Tanah yang bersangkutan untuk didaftarkan dalam daftar atau daftar-daftar buku tanah yang bersangkutan dan dicatat pada sertifikat. Akta, sertifikat beserta warkah lainnya itu dapat pula dibawa sendiri oleh yang berkepentingan ke Kantor Pendaftaran Tanah, dengan ketentuan bahwa ia memberikan tanda penerimaan kepada Pejabat."(Peraturan Pemerintah Republik Indonesia Nomor 10 Tahun 1961 Tentang Pendaftaran Tanah, 1961)

Tujuan dari pendaftaran tanah antara lain:(Pramukti \& Widayanto, 2015)

1) Untuk memberikan kepastian hukum dan perlindungan hukum kepada pemegang hak atas tanah, satuan rumah susun dan hak-hak lain yang terdaftar agar dengan mudah dapat membuktikan dirinya sebagai pemegang hak yang bersangkutan;

2) Untuk menyediakan nformasi kepada pihak-pihak yang berkepentingan termasuk pemerintah agar dengan mudah dapat memperoleh data yang diperlukandalam mengadakan perbuatan hukum mengenai bidang-bidang tanah dan satuan-satuan rumah susun yang sudah terdaftar;

3) Untuk terselenggaranya tertib administrasi pertanahan. 
Adanya pendaftaran tanah memberikan kepastian hkum bagi pemilik tanah atas tanah tersebut dengan diterbitkannya tanda bukti kepemilikan berupa sertifikat. Dengan adanya sertifikat maka dapat dilihat siapa pemilik tanah tersebut secara sah. Selain itu, sertifikat juga menunjukkan letak tanah dan batas-batas dar tanah itu sehingga hal ini meminimalisasi terjadinya sengketa tanah.

Dengan demikian, meskipun sejak dilakukannya jual beli pembeli sudah menjadi pemilik, tetapi kedudukannya sebagai pemilik barulah sempurna setelah dilakukan pendaftaran peralihan hak atas tanah yang dibelinya kepada Kepala Kantor Pertanahan.

\section{Pertanggungjawaban Notaris Terhadap Akta yang Dibuatnya}

a. Akibat Tidak Terpenuhinya Syarat-Syarat Pembuatan Akta Jual Beli

Tidak terpenuhinya syarat-syarat atau ketentuan-ketentuan yang harus dipenuhi oleh seorang Notaris, dapat mempengaruhi kekuatan dari suatu akta yang dibuatnya. Maka dalam proses pembuatan suatu akta jual beli, seorang Notaris harus memastikan semua syarat-syarat dalam proses jual beli maupun syarat-syarat pembuatan akta telah terpenuhi. Syarat-syarat tersebut merupakan syarat yang telah diatur didalam peraturan perundang-undangan dan peraturan yang terkait. Setelah semua syarat-syaratyang diatur dalam peraturan perundang-undangan terpenuhi, maka akta tersebut dapat dikatakan sebagai suatu akta autentik yang memiliki kekuatan pembuktian yang sempurna. Suatu akta Notaris yang dibuat tidak memenuhi ketentuan yang ada, dapat mengakibatkan kekaburan kepastian hukum yang kemudian memicu timbulnya suatu sengketa antara pihak-pihak yang merasa dirugikan dengan adanya akta tersebut.

Putusan MA Nomor $3811 \mathrm{~K} / \mathrm{Pdt} / 2016$ merupakan satu diantara berbagai peradilan yang bergulir guna menentukan keabsahan mengenai kepemilikan atas suatu bidang tanah yang didasarkan dari proses jual beli yang tentu saja berkaitan dengan pemenuhan wewenang dan kewajiban dari seorang notaris dalam menjalankan jabatannya. Pada kasus ini, Notaris yang bersangkutan terbukti tidak memenuhi kewajibannya yang diatur didalam Pasal 16 ayat (1) huruf m atau Pasal 16 ayat (7) UUJN yaitu membacakan akta dihadapan para pihak dan juga saksi-saksi. Maka oleh Hakim, sesuai dengan ketentuan Pasal 41 UUJN, suatu akta autentik yang tidak memenuhi ketentuan-ketentuan Pasal 38, Pasal 39, dan Pasal 40 UUJN akan mengalami degradasi kekuatan hukum dan hanya memiliki kekuatan pembuktian sebagai akta di bawah tangan karena dianggap cacat hukum. Degradasi kekuatan 
pembuktian akta ini membuat perbedaan signifikan dalam kedudukannya sebagai alat bukti dihadapan hakim. Akta autentik merupakan bukti yang mengikat yang berarti kebenaran dari hal-hal atau keterangan-keterangan yang ada dalam akta harus diakui oleh hakim, artinya disini akta dianggap benar selama tidak ada pihak lain yang dapat membuktikan kebenaran sebaliknya.(Ngadino, 2019) Sedangkan akta dibawah tangan, dapat memiliki kekuatan pembuktian yang sempurna hanya apabila akta tersebut diakui oleh para pihak yang membuatnya, sebagaimana yang disebutkan dalam Pasal 1875 KUH Perdata, yaitu:

"Suatu tulisan di bawah tangan yang diakui oleh orang terhadap siapa tulisan itu hendak dipakai, atau yang dengan cara menurut undang-undang dianggap sebagai diakui, memberikan terhadap orang-orang yang menandatanganinya serta para ahli warisnya dan orang-orang yang mendapat hak dari pada mereka, bukti yang sempurna seperti suatu akta autentik, dan demikian pula berlakulah ketentuan Pasal 1871 untuk tulisan itu.'(Kitab Undang-Undang Hukum Perdata, n.d.)

Selain dapat mengalami degradasi kekuatan hukum bilamana tidak memenuhi ketentuan didalam UUJN, suatu akta dapat juga menjadi batal demi hukum atau dibatalkandemi hukum karena tidak memenuhi ketentuan syarat sahnya suatu perjanjian yang diatur didalam Pasal 1320 KUH Perdata. Menurut Moechtar, baik alat bukti akta di bawah tangan maupun akta autentik, keduanya harus memenuhi rumusan mengenai sahnya suatu perjanjian berdasarkan Pasal 1320 Burgerlijk Wetboek (KUH Perdata) dan secara materai mengikat para pihak yang membuatnya sebagai suatu perjanjian yang harus ditepati oleh para pihak (pacta sunt servanda).(Moechthar, 2017) Syarat sahnya suatu perjanjian menurut rumusan Pasal 1320 KUH Perdata, yaitu:

1) Sepakat mereka yang mengikatkan dirinya;

2) Kecakapan untuk membuat suatu perikatan;

3) Suatu hal tertentu;

4) Suatu sebab yang halal.

Tidak terpenuhinya salah satu atau lebih dari syarat-syarat sahnya kontrak tersebut dapat membawa konsekuensi secara yuridis, antara lain:(Djulaeka, 2019)

1) Batal demi hukum (nietig, null and void), apabila yang dilanggarnya merupakan syarat objektif, yaitu perihal tertentu dan kausa yang legal; 
2) Dapat dibatalkan (vernietigbaar, voidable), apabila yang dilanggarnya syarat subjektif, yaitu kesepakatan kehendak dan kecakapan berbuat.

b. Pertanggungjawaban Notaris

Pada dasarnya pertanggungjawaban seorang notaris itu terbatas hanya ada pada suatu kesalahan atau pelanggaran yang disengaja oleh notaris sehingga melanggar ketentuan yang sudah ditetapkan dalam aturan atau perundang-undangan yang mengaturnya saja. Dalam hal terdapat suatu kesalahan atau pelanggaran yang dilakukan oleh penghadap, Notaris tidak dapat dimintai suatu pertanggungjawaban bilamana notaris telah melaksanakan kewajiban dan kewenangannya sesuai koridor hukum yang berlaku. Dengan kata lain, pertanggungjawaban seorang notaris menganut prinsip based on fault liability.

Menurut Abdul Ghofur, tanggungjawab Notaris selaku pejabat umum yang berhubungan dengan kebenaran materiil terhadap akta yang dibuatnya, dibedakan menjadi empat poin, yakni:(Ansori, 2009)

1) Tanggung jawab notaris secara perdata terhadap kebenaran materiil terhadap akta yang dibuatnya;

2) Tanggung jawab notaris secara pidana terhadap kebenaran materiil dalam akta yang dibuatnya;

3) Tanggung jawab notaris berdasarkan peraturan jabatan notaris (UUJN) terhadap kebenaran materiil dalam akta yang dibuatnya;

4) Tanggung jawab notaris dalam menjalankan tugas jabatannya berdasarkan kode etik notaris.

Notaris dapat dituntut bertanggungjawab secara perdata apabila para pihak melakukan pengingkaran:(Afifah, 2017b)

1) Hari, tanggal, bulan, tahun menghadap;

2) Waktu, pukul menghadap;

3) Tanda tangan yang tercantum didalam minuta;

4) Merasa tidak pernah menghadap;

5) Akta tidak ditandatangani didepan notaris;

6) Akta tidak dibacakan;

7) Alasan lain berdasarkan formalitas akta.

Pengingkaran tersebut merupakan bentuk kerugian pada pihak lain yang timbul karena notaris tidak melakukan perbuatan yang seharusnya dilakukannya, sehingga 
notaris dapat dimintakan pertanggung jawabannya dalam konstruksi perbuatan melawan hukum.

Pertanggung jawaban kedua yang dapat dimintakan pada seorang Notaris dalam kapasitasnya sebagai pejabat umum terhadap akta yang dibuatnya yaitu pertanggungjawaban pidana bilamana notaris telah terbukti dengan "sengaja" melakukan pelanggaran yang telah dijabarkan didalam Pasal 55, Pasal 263, dan Pasal 266 KUH Pidana dan telah dilihat di dalam pembuktiannya sejauh mana dia terlibat. Pelaggaran ini di dalam Pasal 264 KUH Pidana diancam dengan sanksi kurungan penjara paling lama delapan tahun.

Selanjutnya pertanggungjawaban yang dapat dimintakan pada notaris yaitu pertanggungjawaban administrasi atas akta yang telah dibuatnya dalam hal dia tidak menjalankan kewajiban yang seharusnya. Pertanggungjawaban administrasi ini dapat dikenakan sanksi seperti yang telah diatur didalam Pasal 16 ayat (11), yaitu :

1) Peringatan tertulis;

2) Pemberhentian sementara;

3) Pemberhentian dengan hormat; atau

4) Pemberhentian dengan tidak hormat.

Ketentuan pertanggungjawaban Notaris di dalam Pasal 65 UUJN sebelum perubahan, berbunyi "Notaris, Notaris Pengganti, Notaris Pengganti Khusus, dan Pejabat Sementara Notaris bertanggungjawab atas setiap akta yang dibuatnya meskipun Protokol Notaris telah diserahkan atau dipindahkan kepada pihak penyimpan Protokol Notaris.”(Undang-Undang Republik Indonesia Nomor 30 Tahun 2004 Tentang Jabatan Notaris, 2004)Rumusan pada pasal ini tidak mengalami perubahan sedikitpun dalam rumusan UU Nomor 2 Tahun 2014. Pada pasal ini tidak dirumuskan secara pasti batas umur pertanggungjawaban dari seorang notaris. Hal ini dapat diartikan bahwa pertanggungjawaban seorang Notaris terhadap akta yang dibuatnya adalah seumur hidup, meskipun Notaris tersebut telah purna tugas dan Protokol Notaris telah diserahkan.

\section{Simpulan}

Berdasarkan hasil penelitian danpembahasan yang telah dipaparkan oleh penulis, maka kesimpulan pertama yang dapat penulis ambil adalah ketentuan yang harus dipenuhi dalam pembuatan suatu akta jual beli yaitu syarat sahnya perjanjian yang diatur didalam Pasal 1320 KUH Perdata serta syarat formil dan materiil yang diatur didalam hukum adat serta PP Nomor 24 Tahun 1997 tentang Pendaftaran Tanah.Tidak terpenuhinya syarat-syarat tersebut 
dapat mengakibatkan degradasi kekuatan pembuktiandari akta autentik menjadi akta dibawah tangan, bahkan dapat dibatalkan atau batal demi hukum.

Kesimpulan kedua yang diambil oleh penulis yaitu,pertanggungjawaban notaris merupakan pertanggungjawaban dengan prinsip based on fault liability. Bentuk pertanggungjawaban yang dapat dimintakan antara lain pertanggung jawaban perdata, pidana, dan administrasi dengan jangka waktu pertanggungjawaban yang berlaku seumur hidup, karena tidakadanya rumusan pasti mengenai batas umur pertanggungjawaban tersebut.

\section{DAFTAR PUSTAKA}

\section{BUKU}

Ansori, A. G. (2009). Lembaga Kenotariatan Indonesia: Perspektif Hukum dan Etika. Yogyakarta: UII Press.

Djulaeka. (2019). Buku Ajar Perancangan Kotrak. Surabaya: Scopindo Media Pustaka.

Kuncoro, N. M. W. (2015). 97 Risiko Transaksi Jual Beli Properti. Jakarta: Raih Asa Sukses.

Mertokusumo, S. (1981). Hukum Acara Perdata. Yogyakarta: Liberty.

Moechthar, O. (2017). Dasar-Dasar Teknik Pembuatan Akta. Surabaya: University Press.

Moechthar, O. (2019). Teknik Pembuatan Akta Badan Hukum dan Badan Usaha di Indonesia. Surbaya: Airlangga University Press.

Ngadino. (2019). Tugas dan Tanggung Jawab Jabatan Notaris di Indonesia. Semarang: Universitas PGRI Semarang Press.

Pengurus Pusat Ikatan Notaris Indonesia. (2008). 100 Tahun Ikatan Notaris Indonesia Jati Diri Notaris Indonesia Dulu, Sekarang, dan di Masa Datang (A. Dwi Saputro, ed.). Jakarta: PT. Gramedia Pustaka.

Pramukti, S., \& Widayanto, E. (2015). Awas Jangan Beli Tanah Sengketa. Yogyakarta: Medpress Digital.

Purnamasari, I. D. (2010a). Kaifa Panduan Lengkap Hukum Praktis Populer: Kiat-Kiat Cerdas, Mudah, dan Bijak Mengatasi Masalah Hukum Pertanahan. Bandung: Penerbit Kaifa PT Mizan Pustaka Anggota IKAPI.

Purnamasari, I. D. (2010b). Kaifa Panduan Lengkap Hukum Praktis Populer: Kiat-Kiat Cerdas, Mudah, dan Bijak Mengatasi Masalah Hukum Pertanahan. Bandung: Penerbit Kaifa PT Mizan Pustaka Anggota IKAPI.

Samudera, T. (2004). Hukum Pembuktian Dalam Acara Perdata. Bandung: Alumni.

Santoso, U. (2017a). Hak Atas Tanah, Hak Pengelolaan, dan Hak Milik Atas Satuan Rumah Susun. Jakarta: Grasindo.

Santoso, U. (2017b). Hak Atas Tanah, Hak Pengelolaan, dan Hak Milik Atas Satuan Rumah Susun. Jakarta: Kencana. 
Sarwat, A. (2018). Fiqih Jual-Beli. Jakarta Selatan: Rumah Fiqih Publishing.

Simbolon, L. A. (2015). Notaris dan Penegakan Hukum Oleh Hakim. Yogyakarta: Deepublish.

Supancana, I. B. R. (2019). Berbagai Perspektif Harmonisasi Hukum Nasional dan Hukum Internasional. Jakarta: Universitas Katolik Indonesia Atma Jaya.

\section{ARTIKEL JURNAL}

Afifah, K. (2017a). Tanggung Jawab dan Perlindungan Hukum bagi Notaris secara Perdata Terhadap Akta yang Dibuatnya. Lex Renaissance, II.

Afifah, K. (2017b). Tanggung Jawab dan Perlindungan Hukum bagi Notaris secara Perdata Terhadap Akta yang Dibuatnya. Lex Renaissance, II, 161.

Rondonuwu, G. (2017a). Kepastian Hukum Peralihan Hak Atas Tanah Melaui Jual Beli Berdasarkan PP Nomor 24 Tahun 1997 Tentang Pendaftaran Tanah. Lex Privatum, V.

Rondonuwu, G. (2017b). Kepastian Hukum Peralihan Hak Atas Tanah Melaui Jual Beli Berdasarkan PP Nomor 24 Tahun 1997 Tentang Pendaftaran Tanah. Lex Privatum, V, 117.

Zulhadji, A. (2016a). Peralihan Hak Atas Tanah Melalui Jual Beli Tanah Menurut Undang Undang Nomor 5 Tahun 1960. Lex Crimen, $V$.

Zulhadji, A. (2016b). Peralihan Hak Atas Tanah Melalui Jual Beli Tanah Menurut Undang Undang Nomor 5 Tahun 1960. Lex Crimen, V, 32.

\section{PERATURAN PERUNDANG-UNDANGAN}

Kitab Undang-Undang Hukum Perdata.

Undang-Undang Republik Indonesia Nomor 2 Tahun 2014 Tentang Perubahan Atas UndangUndang Nomor 30 Tahun 2004 Tentang Jabatan Notaris.

Undang-Undang Republik Indonesia Nomor 30 Tahun 2004 Tentang Jabatan Notaris.

Undang-Undang Republik Indonesia Nomor 5 Tahun 1960 Tentang Peraturan Dasar Pokok-Pokok Agraria.

Peraturan Pemerintah Republik Indonesia Nomor 10 Tahun 1961 Tentang Pendaftaran Tanah. 